\title{
МЕТОДИКА СКЛАДАННЯ МАТЕМАТИЧНОЇ МОДЕЛІ ТА РЕЗУЛЬТАТИ РОЗРАХУНКУ ПОКАЗНИКІВ РУХУ ПЕРЕОБЛАДНАНОГО ЕЛЕКТРИЧНОГО КТЗ КАТЕГОРІЇ М1 В ЇЗДОВОМУ ЦИКЛІ
}

\begin{abstract}
У роботі запропонована методика складання та результати розрахунку за математичною моделлю. Проблема математичного опису функціональних елементів електричних колісних транспортних засобів (ЕКТЗ) ускладнюється необхідністю опису електричних процесів що відбуваються та впливом системи керування на силову установку. Розроблена методика є оригінальною, розглядається система «Силова акумуляторна батарея - Тяговий електродвигун - Трансмісія» в умовах руху за їздовим циклом. Для складання математичної моделі був обраний математичний пакет OpenModelica, це відкрите середовище моделювання та моделювання на основі Modelica. Модель має блок «Водій», який представляє собою замкнений контур контролера керування. Він відслідковує фактичну швидкість електромобіля і порівнює іiі 3 необхідною, заданою їздовим циклом.

Визначені тягово-швидкісні та енергетичні показники переобладнаного автомобіля категорії М1 в батарейний електромобіль. За допомогою розробленої методики, можливо прогнозувати експлуатаційні показники електричного колісного транспортного засобу до виконання переобладнання. В якості вихідних числових значень параметрів переобладнаного автомобіля для проведення числового експерименту 3 використанням ПК, було обрано серійний автомобіль категорії M1 3АЗ-965 «Запорожець». Методика проведення числового експерименту передбачає проведення великої кількості обчислень в різних поєднаннях вихідних параметрів. В подальшому на ньому передбачено проведення дорожніх та стендових випробовувань.

Технічний рівень переобладнання визначається питомою масою та питомою вартістю як окремих агрегатів так і всього електронного обладнання в цілому. Однак, показник вартості обладнання має сильну волатильність, тож його важко оцінити об'єктивно. В роботі пропонується критерій можливості збереження величини повної маси переобладнаного ЕКТЗ, умова обмеження за габаритними розмірами, максимальної кутової швидкості ротора тягового електродвигуна, максимального струму та напруги в силових елементах системи керування.
\end{abstract}

Ключові слова: електромобіль, переобладнання, ефективність, математична модель, контролер, числовий експеримент, енергетична ефективність.

\section{ВСТУП}

Екологічні, економічні та транспортні проблеми міст спонукають людство до пошуку нових типів колісних транспортних засобів (КТЗ) і способів організації міських перевезень. На сьогоднішній день, частка використання електромобілів (EM) та гібридних автомобілів в розвинених країнах поступово збільшується, це підтверджується прогнозом розвитку від Allen Fuhs у своій монографії [1] та сучасними станом електричних КТЗ (ЕКТЗ) [2...5]. Питання утилізації існуючих автомобілів обладнаних ДВЗ враховуючи їх велику кількість по всьому світу створює значну суспільну проблему. Одним із способів ï вирішення є їх переобладнання в ЕКТЗ [6]. Дуже часто таке переобладнання здійснюється власниками старих серійних автомобілів 3 ДВЗ, при цьому не проводиться жодних досліджень щодо його доцільності. Відсутність рекомендацій щодо вибору функціональних елементів ЕКТЗ та методики розрахунку експлуатаційних властивостей переобладнаних ЕКТЗ ускладнює цей процес. Явище переобладнання КТЗ є характерним для країн всього світу, а не тільки для України. До країн в яких широко розповсюджене переобладнання належать: США, Канада, країни Європи, Індія та Китай. Виконувати роботи 3 переобладнання можуть спеціалізовані фірми або індивідуальні власники автомобілів купуючи набори для переобладнання чи створюючи свої власні розробки. Перевіркою безпечності виконаних робіт займаються державні або сертифіковані органи з оцінки відповідності конструкції КТЗ.

\section{АНАЛІЗ ЛІТЕРАТУРНИХ ДАНИХ ТА ПОСТАНОВКА ПРОБЛЕМИ}

Проблеми дослідження та визначення показників тягово-швидкісних властивостей та енергетичної ефективності ЕКТЗ присвячено багато робіт, оскільки вони $є$ важливими характеристиками, які визначають його поведінку під впливом зовнішніх факторів. Відомо багато робіт вітчизняних вчених: проф. Сахно В.П., доц. Поляков В.М., доц. Тімков О.М., проф. Клепіков В.Б., проф. Павлов В.Б, доц. Сітовский О.П., доц. Дембіцький В.М., проф. Двадненко В.Я., проф. Туренко А.М., проф. Гнатов А.В., проф. Богомолов В.А., проф. Абрамчук Ф.І., проф. Бажинов А.В. i багато інших вчених. 
Аналіз сучасного стану досліджень ЕКТЗ показав, що роль аналітичних методів залишається надзвичайно великою. Висока їх роль і в кількісному визначенні параметрів експлуатаційних властивостей, але точність розрахунків при цьому обмежена. Кількісні характеристики, що одержують за допомогою аналітичних методів, в основному є першими оцінками, які надають уявлення про порядок досліджуваних параметрів і про напрямок розвитку процесу. Точність таких оцінок не варто збільшувати за рахунок ускладнення аналітичного апарату — для точних розрахунків краще користуватися чисельними методами з використанням ПК. В останньому випадку аналітичні методи не можуть конкурувати 3 ними.

\section{ЦІЛЬ ТА ЗАДАЧІ ДОСЛІДЖЕННЯ}

Розробка методики складання математичної моделі (ММ) силової установки (СУ) і показників руху переобладнаного ЕКТЗ категорії М1 є актуальним завданням сьогодення. За допомогою якої, було б можливим прогнозування його експлуатаційних показників до виконання переобладнання.

\section{РЕЗУЛЬТАТИ ДОСЛІДЖЕНЬ}

Моделювання ЕКТЗ - це складне завдання, яке потребує цілого комплексу знань та навичок. Необхідно вирішувати завдання моделювання обертального руху, механіки поступального руху, електричних машин і перетворювачів, гідравлічних компонентів і систем та багато іншого. Зокрема, моделювання ЕКТЗ не може бути повним без сполучення електричної і механічної частин та їх систем контролю та керування.

OpenModelica це відкрите середовище моделювання та моделювання на основі Modelica, призначене для промислового та академічного використання. Вона доступна безкоштовно, на різних платформах (Windows, Mac, Unix) зі свого офіційного сайту, http://www.openmodelica.org [7].

Bci зображення інструменту Modelica, включені в цю роботу, взяті з OpenModelica. Modelica дозволяє виконувати роботи, подібні до тих, що можна виконати в лабораторії, проводячи тести на натурному транспортному засобі. 3 тією перевагою, що можливо все виміряти без необхідності будувати складні вимірювальні комплекси. Також можливо все змінити в фізичній та контрольній частинах нашої системи, не витрачаючи великі кошти або ризикуючи пошкодженням обладнання. Використовуючи основні положення з роботі [8], була створена та реалізована в середовищі Modelica математична модель переобладнаного ЕКТЗ [9].

Спрощене уявлення про силову установку ЕКТЗ з використанням компонентів MSL i схеми Modelica наведено на рис. 1, це імітаційна модель.

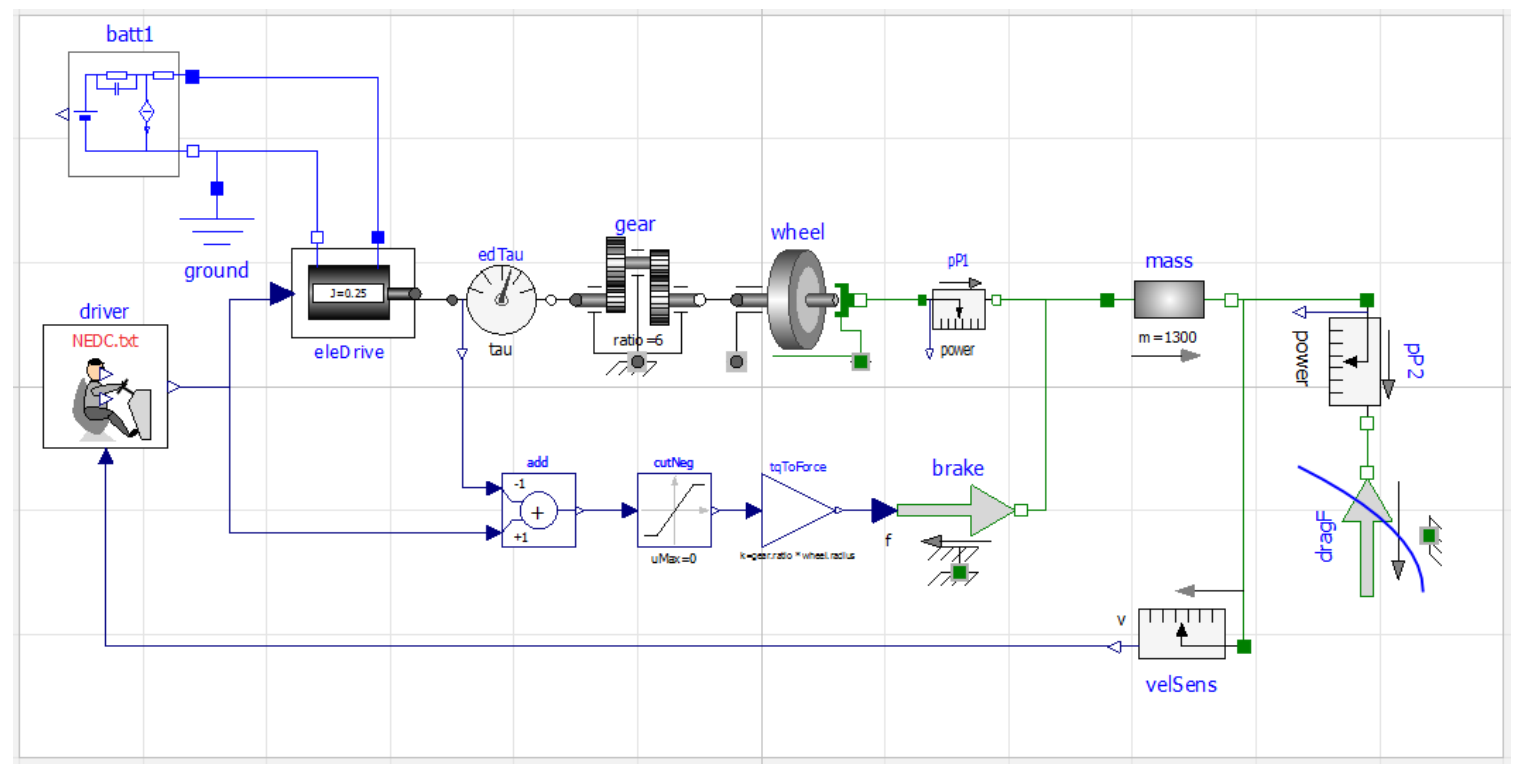

Рисунок 1 - Структурна модель переобладнаного ЕКТЗ в середовищі OpenModelica

Водій (driver). Неможливо 3 високою точністю змоделювати транспортний засіб, не включивши в нього модель водія. У своїй роботі будемо використовувати модель водія, яка здатна забезпечувати швидкісний режим руху заданий умовами їздового циклу.

Датчик швидкості автомобіля (velSens) створює комунікаційний зв'язок між фізичною та віртуальною частинами нашої імітаційної моделі. Інакше кажучи, він відіграє функцію панелі приладів автомобіля. Водій має бачити кінематичний цикл, який він хоче виконати, і для цього він діє 
як замкнутий контур контролера керування. Тому він відслідковує фактичну швидкість через приладову панель (яка в нашій свідомості відображає швидкість, виміряну датчиком), порівнює ії 3 необхідною, заданою їздовим циклом. Контролер діє на органи керування (гальмо та акселератор) таким чином, щоб зменшити або звести нанівець похибку керування.

В якості вихідних числових значень параметрів ЕКТЗ для проведення числового експерименту з використанням ПК, було обрано наступні вихідні параметри переобладнаного в ЕМ серійного автомобіля категорії M1 3АЗ-965 «Запорожець», (табл. 1), технічні показники якого було взято $з$ джерела [10]. Цей автомобіль був обраний для розрахунків, тому що, в подальшому на ньому передбачається проведення дорожніх та стендових експериментальних досліджень.

Таблиця 1 - Технічна характеристика 3АЗ -965 «Запорожець»

\begin{tabular}{|c|c|c|}
\hline \multicolumn{2}{|l|}{ Параметр } & Величина \\
\hline \multicolumn{2}{|l|}{ Двигун } & $\begin{array}{l}\text { бензиновий } \mathrm{V} \text {-подібний } 0,887 \text { л при } 4000- \\
4200 \text { об/хв }\end{array}$ \\
\hline \multicolumn{2}{|l|}{ Коробка передач } & $\begin{array}{l}4 \text { передачі; I - 3,73; II - 2,29; III - 1,39; IV - } \\
\text { 0.964; 3.X. -4,76 }\end{array}$ \\
\hline \multicolumn{2}{|l|}{ Головна передача } & одинарна; 4,63 \\
\hline \multicolumn{2}{|l|}{ Лобова площа } & $1,43 \mathrm{~m}^{2}$ \\
\hline \multicolumn{2}{|c|}{ Коефіцієнт обтічності } & $0,47 \ldots 0,52$ \\
\hline \multirow{3}{*}{$\begin{array}{l}\text { Габаритні } \\
\text { розміри }\end{array}$} & довжина & $3330 \mathrm{MM}$ \\
\hline & ширина & $1395 \mathrm{MM}$ \\
\hline & висота & $1450 \mathrm{MM}$ \\
\hline \multicolumn{2}{|l|}{ Колісна база } & $2023 \mathrm{MM}$ \\
\hline \multirow[t]{2}{*}{ Колія } & передня & $1150 \mathrm{MM}$ \\
\hline & задня & $1160 \mathrm{MM}$ \\
\hline \multicolumn{2}{|c|}{ Максимальна швидкість } & 100 км/год \\
\hline \multirow[t]{2}{*}{ Маса автомобіля } & споряджена & 693 кг \\
\hline & повна & 950 кг \\
\hline \multirow[t]{3}{*}{ Шин: } & тип & безкамерні \\
\hline & розмір & 175/70 R13 «Rosava» \\
\hline & $\begin{array}{l}\text { радіус } \\
\text { кочення }\end{array}$ & $0,282 \mathrm{M}$ \\
\hline
\end{tabular}

Повною мірою задачу вибору та обгрунтування параметрів силової установки (СУ) ЕКТЗ можливо вирішити якщо розрахунки засновано на раціонально обраних вихідних даних, що об’ єктивно відображають особливості роботи СУ в системі «САКБ - ТЕД - Трансмісія» (САКБ силова акумуляторна батарея, ТЕД - тяговий електродвигун). Практика проектування свідчить, що саме знаходження вихідних даних та внутрішніх параметрів системи $є$ найбільш складною задачею. Маючі в якості початкових даних таки параметри переобладнаного ЕКТЗ як, геометричні та масові параметри серійного КТЗ, передаточне відношення головної передачі, яка в більшості випадків не змінюється та умови руху в їздовому циклі, якому має відповідати переобладнаний ЕКТЗ. Кожному набору вихідних даних СУ може відповідати множина параметрів САКБ (тип акумуляторного елемента (AE), їх кількість, тип їх з'єднання, повна ємність, вага та ін.), ТЕД (номінальна напруга, частота струму, перевантажувальна здатність, максимальна напруга та струм тощо) та ін. Завдання що слід вирішити представлені на рис. 2.

Методика проведення числового експерименту передбачає проведення великої кількості обчислень в різних поєднаннях вихідних параметрів. Загальна кількість варіантів $n_{E M}$, що мають бути розглянуті в процесі переобладнання ЕКТЗ складатиме:

$$
n_{E M}=n_{\text {САКБ }} n_{\text {ТЕД }} n_{U}
$$

де $n_{\text {САКБ }}$ - число варіантів параметрів САКБ;

$n_{\text {ТЕд }}-$ число варіантів параметрів ТЕД;

$n_{U}-$ передаточне відношення головної передачі. 


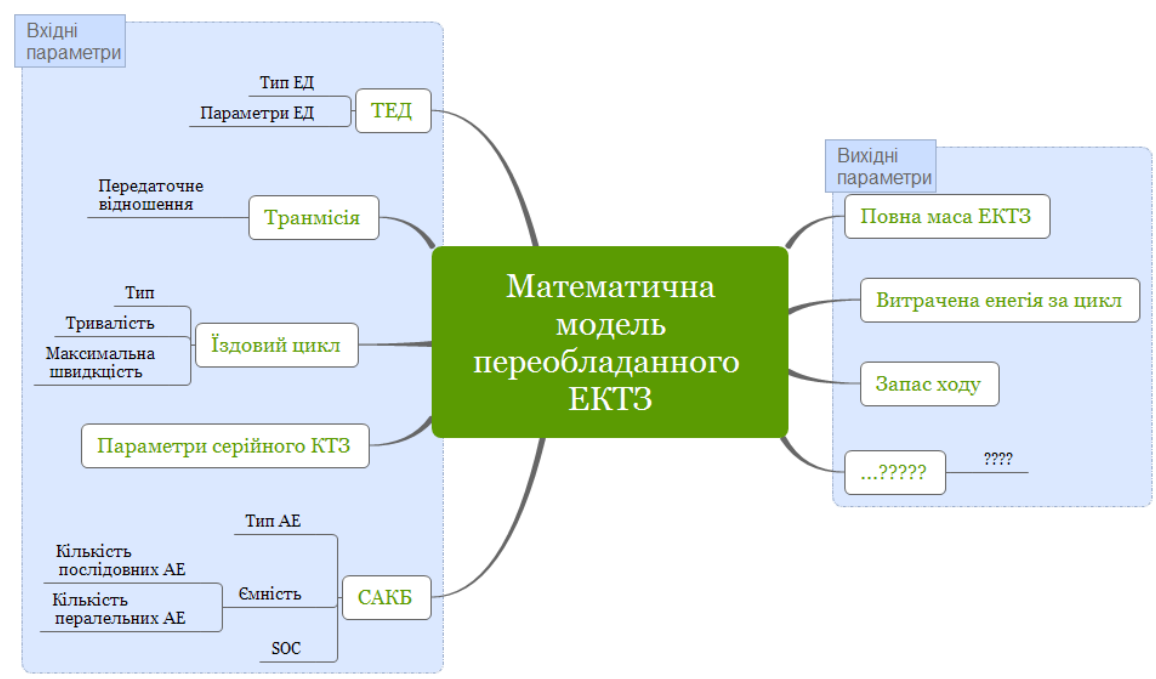

Рисунок 2 - Множина вхідних та вихідних параметрів ММ

Враховуючи це, можна зробити висновок, що вибір вихідних даних для переобладнання ЕКТЗ $\epsilon$ вельми громіздка та складна задача, розв'язати яку можливо лише при наявності певної методики. Маючі вхідні параметри та вливаючи на них, можна отримати комплексні вихідні величини за якими можна оцінити ступінь відповідності проведеного переобладнання поставленим критеріям.

В якості прикладу, наведені результати розрахунків за ММ в графічному вигляді при русі переобладнаного EM за їздовим циклом WLTP клас 1. Отримані різні залежності, а саме, рівень заряду САКБ (рис. 3), залежність фактичної та бажаної швидкості ЕМ (рис. 4). На ньому, фактична швидкість (червона) і бажана швидкість (синя) знаходяться дуже близько одна від одної. Зміна напруги на САКБ (рис. 5).

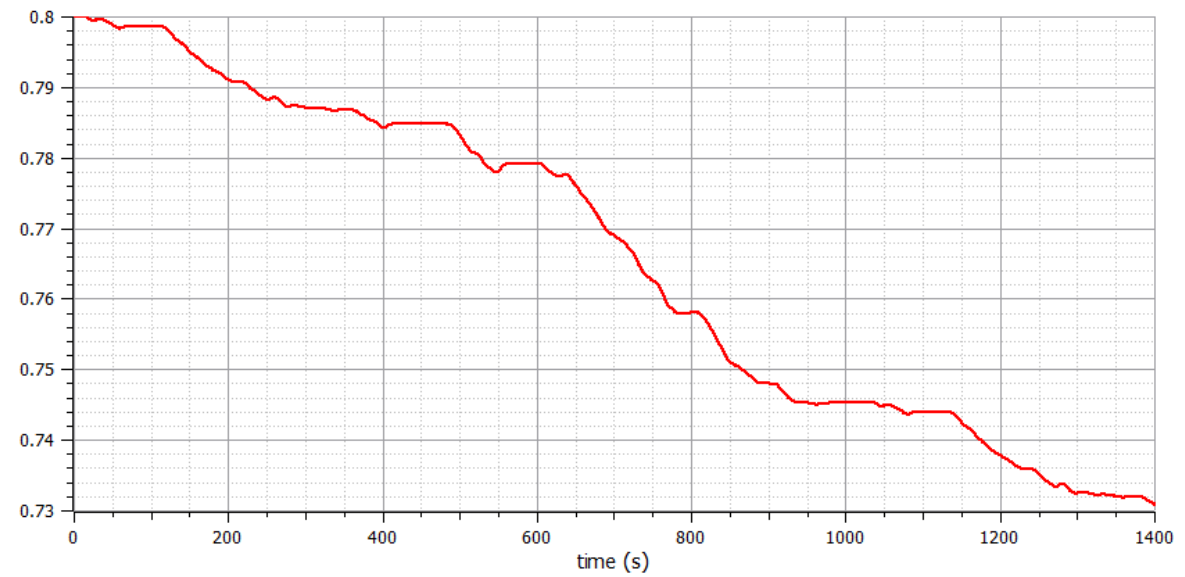

Рисунок 3 - Графік рівня заряду САКБ (SOC)

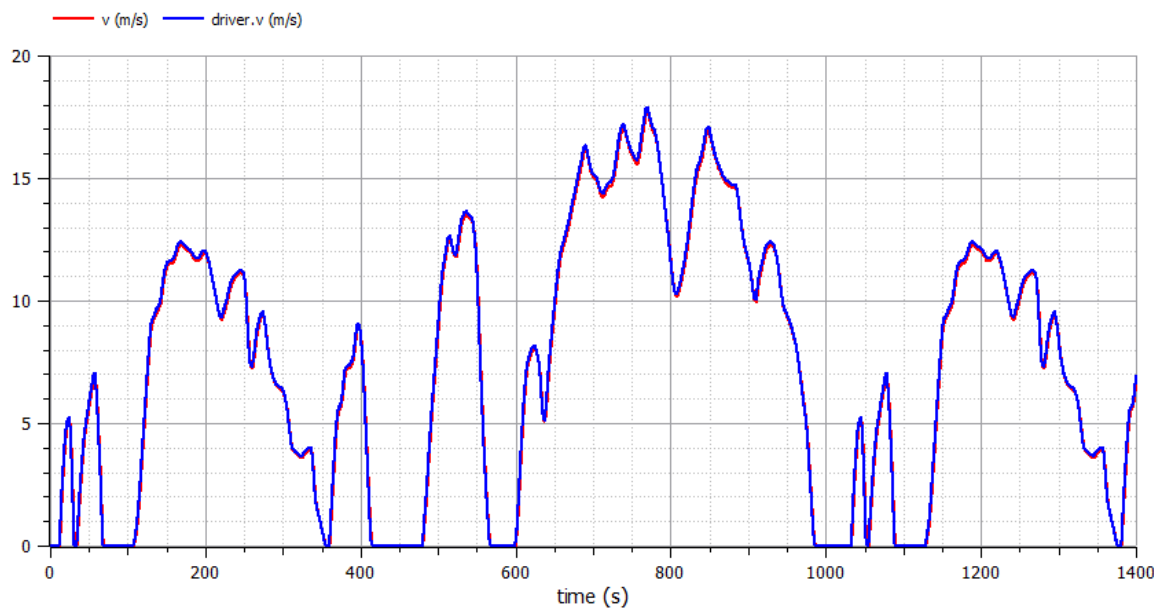

Рисунок 4 - Графік фактичної та бажаної швидкості ЕМ 


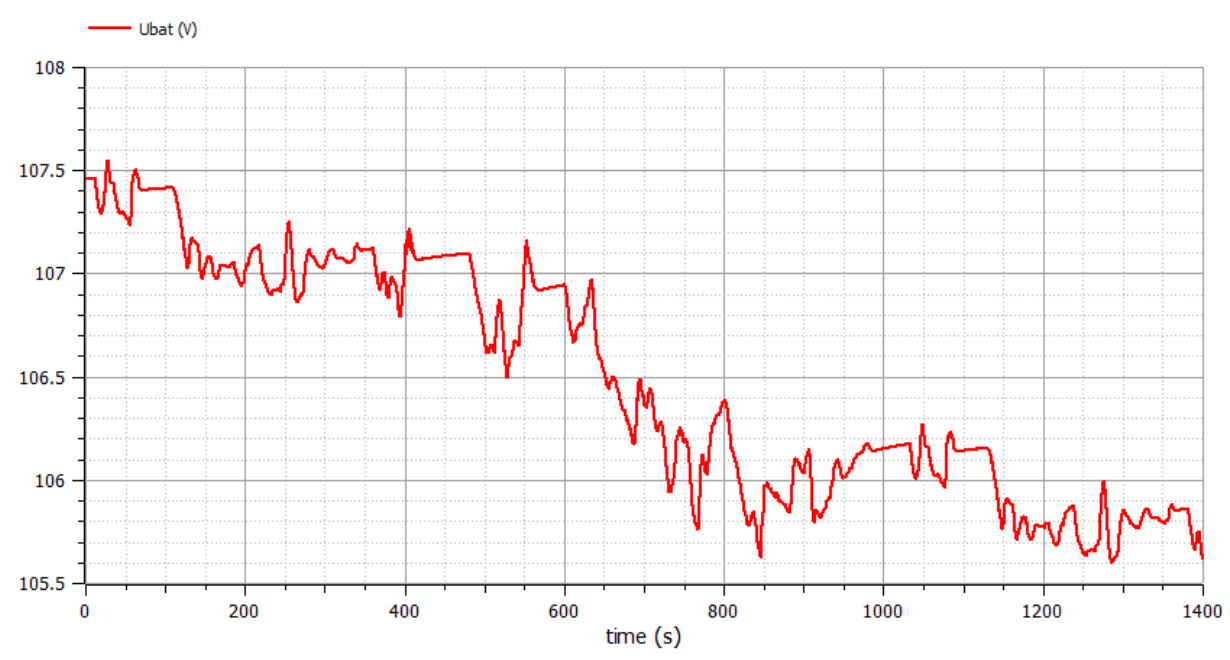

Рисунок 5 - Графік зміни напругу на САКБ

Зміна крутних моментів (рис. 6), показує потрібний крутний момент (червоний), дійсний крутний момент, що розвиває ТЕП (синій), крутний момент, що відповідає електричному гальмівному зусиллю (зелений).

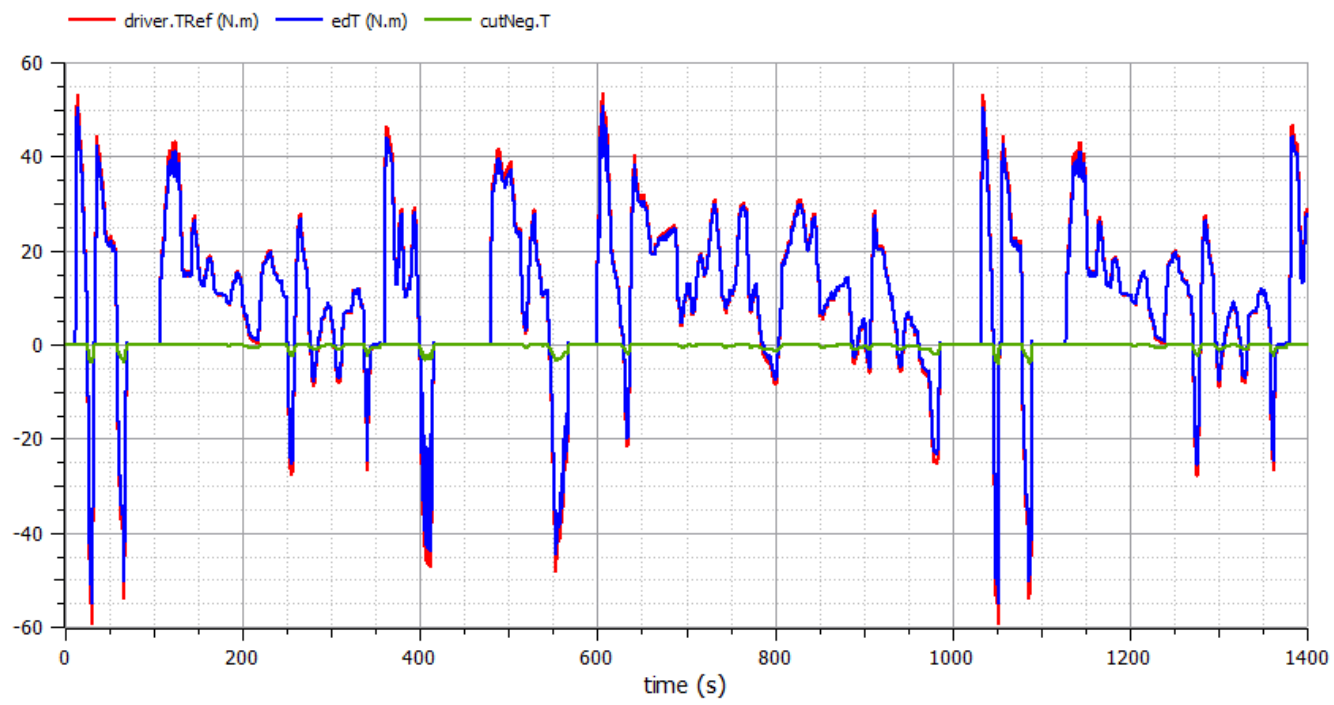

Рисунок 6 - Графік зміни крутних моментів

Аналізуючи графічні залежності можна зазначити, що:

- додатні крутні моменти, більше ніж 40 Нм потрібні для повного виконання умов їздового циклу. В реалізованій ММ їх запитує водій, але, СУ не може їх реалізувати. Це звичайне явище для КТЗ, коли водій вимагає крутний момент, що перевищує максимально можливий, в цьому випадку, це практично не впливає на бажану швидкість КТЗ.

- негативні крутні моменти майже завжди реалізуються при електричному гальмуванні. Механічне гальмування тут відбувається тільки при повному гальмуванні. Особливо це помітно для класів 2 та 3 де $\epsilon$ позаміська частина їздового циклу (ділянки 3 високою та надзвичайно високою швидкістю). Однак на практиці реальні ЕМ частіше використовують механічне гальмування.

Витрати енергії при русі переобладнаного ЕM за їздовим циклом WLTP клас 1 (рис. 7).

Змінна enDTdel - це енергія, що подається силовою передачею, в той час як enP1Del - це енергія, що подається на лівий фланець маси: дві сили відрізняються одна від одної тільки при зміні швидкості: область між кривими - це кінетична енергія, запасена в інерції трансмісії, вона компенсує одна одну.

Загальна ефективність ЕМ не дуже висока, через передбачувану карту ефективності; нарешті, синя крива показує енергію, втрачену всередині батареї, в її внутрішньому опорі та інших елементах розсіювання. Однак для оцінки ефективності циклу роботи акумулятора його слід спочатку 
підзарядити. Зелена крива - енергія яка була втрачена при механічному гальмуванні в гальмівних механізмах EM.

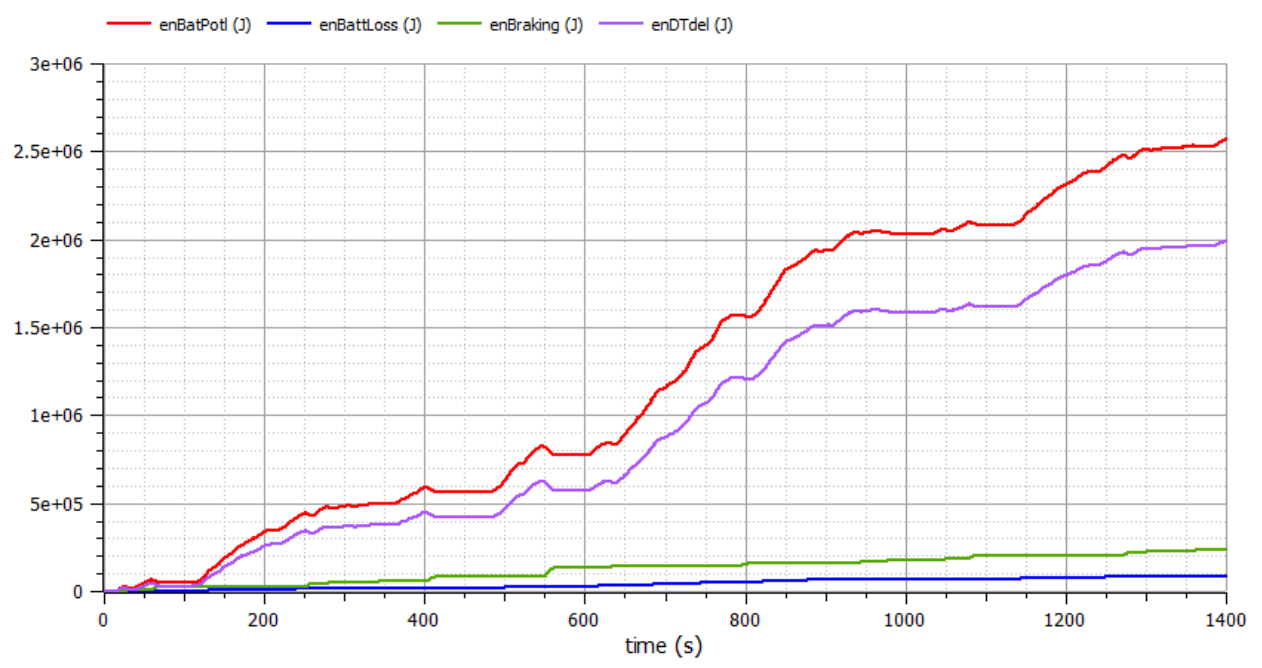

Рисунок 7 - Витрата енергії переобладнаного ЕМ

Діаграма фактичних крутних моментів тягового електропривода (рис. 8) та обмеження крутного моменту що накладає використаний тип ТЕД представлено у параметричному вигляді. Графік показує робочі точки СУ ЕМ при русі в їздовому циклі. Всі точки знаходяться в середині, що свідчить про наявний надлишковий крутний момент ТЕП.

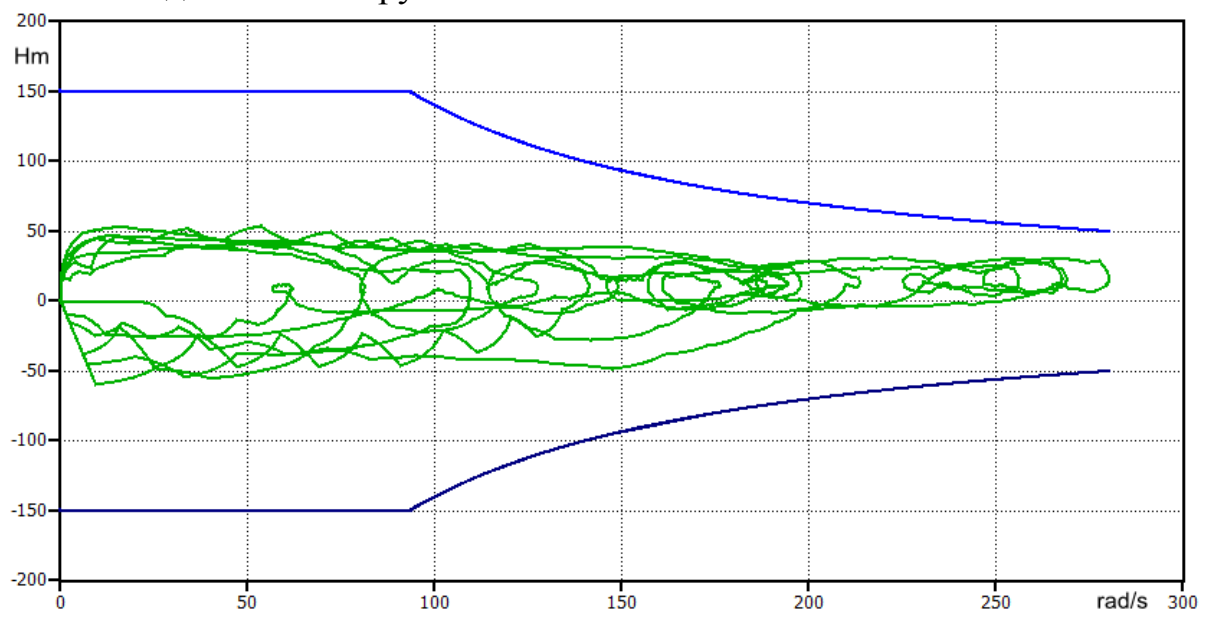

Рисунок 8 - Робоча карта фактичних крутних моментів ТЕП (зелені) та обмежень (сині)

Сині криві - це максимальний і мінімальний допустимі крутні моменти ЕД. Крива запиту водієм, завжди залишається всередині і відображається зеленим кольором; коли вона виходить за межі, вона відображається червоним кольором, це трапляється для класів 2 та 3 або при недостатній потужності електродвигуна.

Дослідження переобладнаного ЕМ полягає в оцінці фактичних робочих точок СУ (тобто точок, що належать зеленій кривій на робочій карті вище). Їх порівняння з картами ефективності ЕД дозволяє оцінити його ККД, у випадках, якщо ККД занадто часто залишається низьким, це свідчить про необхідність зміни вихідних параметрів моделі, а саме в конструкції силової установки.

\section{ОБГОВОРЕННЯ РЕЗУЛЬТАТІВ ДОСЛІДЖЕННЯ}

Вибір та обгрунтування раціональних параметрів системи «САКБ - ТЕД - Трансмісія»є складною задачею. В залежності від категорії КТЗ, його призначення та умов експлуатації, критерії раціональності можуть бути різні. Тобто, слід надавати більшу вагу різним показникам системи переобладнаного ЕКТЗ. Найбільш поширеним та універсальним критерієм раціональності вибору $є$ мінімум приведених витрат, пов'язаних через розрахункову потужність 3 масою та вартістю обладнання. Технічний рівень переобладнання визначається питомою масою та питомою вартістю як окремих агрегатів так і всього електронного обладнання в цілому. Однак, показник вартості обладнання має сильну волатильність, тож його важко оцінити об'єктивно. 
В роботі пропонується критерій можливості збереження величини повної маси переобладнаного ЕКТЗ, умова обмеження за габаритними розмірами, максимальної кутової швидкості ротора ТЕД, максимального струму та напруги в САКБ та силових елементах САУ.

\section{ВИСНОВКИ}

Проблема математичного опису функціональних елементів електромобіля та гібридних автомобілів різних типів ускладнюється описом електричних процесів що відбуваються та впливом системи керування на силову установку.

Одним 3 шляхів вирішення цієї проблеми є використання математичних пакетів прикладних програм які мають у своєму складі готові бібліотеки механічних, електричних та комунікаційних елементів систем. Задачею дослідника в цьому випадку є правильне поєднання та налаштування елементів та подальша перевірка адекватності розробленої математичної моделі з результатами натурних досліджень на КТЗ.

Розроблена та використана методика вибору i обгрунтування раціональних параметрів системи «САКБ - ТЕД - Трансмісія» переобладнаного ЕКТЗ категорії М1, на підставі моделювання процесів розряду САКБ при русі в їздовому циклі WLTP клас 1 за допомогою елементів теорії планування експерименту.

В подальшому планується проведення дорожніх та стендових випробовувань переобладнаного ЕКТЗ за обраними вихідними даними для автомобіля ЗАЗ - 965 «Запорожець». На основі результатів дослідження буде проведена перевірка адекватності розробленої математичної моделі.

\section{ПЕРЕЛІК ДЖЕРЕЛ ПОСИЛАННЯ}

1.Allen Fuhs E. Hybrid vehicles and the future of personal transportation. CRC Press Taylor\&Francis Group. Boca Raton. Vol. Hybrid electric cars. 505 p.

2.Мировой рынок электромобилей в 2020 году вырос на 43\%. [Electronic resource] // TAdviser.ru. URL: /index.php/Статья:Электромобили_(мировой_рынок) (accessed: 15.02.2021).

3.Toyota Mirai. Вікіпедія. 2021. [Electronic resource] // URL: https://uk.wikipedia.org/wiki/Toyota_Mirai (accessed: 15.02.2021).

4.Lightyear One - Long Range Solar Car [Electronic resource]. URL: https://lightyear.one/ (accessed: 15.02.2021).

5.Larminie J., Lowry J. Electric Vehicle Technology Explained, 2nd Edition / Wiley. John Wiley \& Sons, 2003.

6.Грищук О.К. Щодо переобладнання автомобіля шляхом заміни двигуна внутрішнього згоряння на електромотор / О.К. Грищук, В.С. Гладченко, Ю.М. Оверченко // Перевізник UA № 1/2020, С. 2022/

7.Welcome to OpenModelica - OpenModelica [Electronic resource]. URL: https:// www.openmodelica.org/ (accessed: 29.06.2020)

8.Тімков О.М. Методика розробки математичної моделі електромобіля у відповідності до його компонувальної схеми / О.М. Тімков, В.С. Гладченко, М.М. Гордієнко// Вісник ЖДТУ, Серія. Автомобільний транспорт. № 2 (84) 2019, С. 10-15. DOI: https://doi.org/10.26642/ten-2019-2(84)-10-15 ISSN 2706-5847.

9.Побудова математичної моделі електромобіля в середовищі Modelica / В.С. Гладченко, О.К. Грищук //Матеріали II Всеукраїнська конферениія молодих вчених «Молодь i наука. Практика інновачійного пошуку» (17.12. 2020 р., м. Дніпро, Україна), - С. 250 - 253. ISBN 978-617-7891-06-1.

10.Автомобиль “Запорожець” моделей 3АЗ-965А и ЗАЗ-965АБ. Руководство по эксплуатации и ремонту. 4th ed. Днепропетровск: Промінь, 1968. 217 с.

\section{REFERENCES}

1.Allen Fuhs E. Hybrid vehicles and the future of personal transportation. CRC Press Taylor\&Francis Group. Boca Raton. Vol. Hybrid electric cars. 505 p.

2.Myrovoy rynok elektromobyley v 2020 hodu vyros na 43\%. [Electronic resource] // TAdviser.ru. URL: /index.php/Статья:Электромобили_(мировой_рынок) (accessed: 15.02.2021).

3.Toyota Mirai. Vikipediia. 2021. [Electronic resource] // URL: https://uk.wikipedia.org/wiki/Toyota_Mirai (accessed: 15.02.2021).

4.Lightyear One - Long Range Solar Car [Electronic resource]. URL: https://lightyear.one/ (accessed: 15.02.2021). 
5.Larminie J., Lowry J. Electric Vehicle Technology Explained, 2nd Edition / Wiley. John Wiley \& Sons, 2003.

6.Hryshchuk O.K. Shchodo pereobladnannia avtomobilia shliakhom zaminy dvyhuna vnutrishnoho zghoriannia na elektromotor / O.K. Hryshchuk, V.S. Hladchenko, Yu.M. Overchenko // Pereviznyk UA № 1/2020, P. 20-22/

7.Welcome to OpenModelica - OpenModelica [Electronic resource]. URL: https://www.openmodelica.org/ (accessed: 29.06.2020)

8.Timkov O.M. Metodyka rozrobky matematychnoi modeli elektromobilia u vidpovidnosti do yoho komponuvalnoi skhemy / O.M. Timkov, V.S. Hladchenko, M.M. Hordiienko // Visnyk ZhDTU, Seriia. Avtomobilnyi transport. № 2 (84) 2019, P. 10-15. DOI: https://doi.org/10.26642/ten-2019-2(84)-10-15 ISSN 2706-5847.

9.Pobudova matematychnoi modeli elektromobilia v seredovyshchi Modelica / V.S. Hladchenko, O.K. Hryshchuk // Materialy II Vseukrainska konferentsiia molodykh vchenykh «Molod i nauka. Praktyka innovatsiinoho poshuku» (17.12.2020 r., m. Dnipro, Ukraina), - P. 250 - 253. ISBN 978-617-7891-06-1.

10.Avtomobyl "Zaporozhets" modelei ZAZ-965A y ZAZ-965AB. Rukovodstvo po ekspluatatsyy y remontu. 4th ed. Dnepropetrovsk: Promin, 1968. 217 p.

\section{Hladchenko $V$., Overchenko $U$. Method of compilation of the mathematical model and results of calculation of movement indicators of the re-equipped electromobile of category $M 1$ in road test procedure}

The method of addition and results of calculation according to the mathematical model are offered in the article. The problem of mathematical description of the functional elements of electric wheeled vehicles (EWV) is complicated by the need to describe the electrical processes that occur and the influence of the control system on the power plant.

The developed method is original, the system "Power accumulator battery - Traction electric motor - Transmission" in the conditions of movement on a driving cycle is considered.

The OpenModelica mathematical package, an open modeling and modeling environment based on Modelica, was chosen to compile the mathematical model. The model has a "Driver" unit, which is a closed loop control controller. It monitors the actual speed of the electric car and compares it with the required, set driving cycle.

The traction-speed and energy indicators of the converted M1 vehicle into a battery electromobile are determined. With the help of the developed technique, it is possible to predict the performance of EWV before the conversion. As initial numerical values of parameters of the re-equipped vehicle for carrying out numerical experiment with use of the personal computer, the common vehicle of the M1 ZAZ-965 "Zaporozhets" category was chosen. The method of conducting a numerical experiment involves a large number of calculations in different combinations of initial parameters. In the future, it provides for road and bench tests.

The technical level of re-equipment is determined by the specific weight and unit cost of both individual units and all electronic equipment as a whole. However, the cost of equipment is highly volatile, so it is difficult to assess it objectively. The paper proposes the criterion of the possibility of preserving the value of the total mass of the converted ECT, the condition of limitation in overall dimensions, the maximum angular velocity of the rotor of the traction motor, the maximum current and voltage in the power elements of the control system.

Key words: electromobile, re-equipment, efficiency, mathematical model, controller, numerical experiment, energy efficiency.

ГЛАДЧЕНКО Володимир Сергійович, аспірант кафедри туризму Національного транспортного університету e-mail: v.glad4enko@ukr.net. https://orcid.org/0000-0001-5783-4880

ОВЕРЧЕНКО Юрій Миколайович, провідний інженер ДП «ДержавтотрансНДІпроект» e-mail: yoverchenko@insat.org.https://orcid.org/0000-0001-6307-3459

Volodimir HLADCHENKO, graduate student of the Department of Tourism the National Transport University e-mail: v.glad4enko@ukr.net.https://orcid.org/0000-0001-5783-4880

Uriy OVERCHENKO, Senior Engineer of the Department of Scientific and Technical Expertise, the State Road Transport Research Institute e-mail: yoverchenko@insat.org.ua . https://orcid.org/0000-0001-6307$\underline{3459}$

DOI 10.36910/automash.v1i16.507 